\title{
Synthesis and Characterization of Complexes Formed by Transition Metal Ions With Thiophene Imides As Potential Precursors To Metal Ion Uptake and Release Agents
}

\author{
Rosalva C. Garcia, Kasha Patel, Cynthia S. Day, and Ronald E. Noftle* \\ Department of Chemistry, Wake Forest University, Winston-Salem, NC 27109, USA \\ *corresponding author: noftle@wfu.edu
}

\section{Introduction:}

In a previous paper ${ }^{1}$, we reported on the preparation, and structural characterization of a series of alkyl-3-thienylimides as well as on their electrochemistry. We had observed that the imide function is an electronic analog of acetylacetone which is often used as a textbook example of a chelating group which coordinates a wide variety of metal ions ${ }^{2}$. Scheme 1 shows the thiophene derivative of acetylacetone and acetylacetone. The acetylacetone moiety in 2thienyl(trifluoroacetyl)acetone has been used widely as a taggant in biochemical systems ${ }^{3}$. A variety of transition metal complexes, mostly of iron and copper, has been prepared with neutral imide ligands containing both coordinating nitrogen (from associated rings) and oxygen from the imide moiety ${ }^{4}$, but only a relatively small number of bidentate acyclic imide metal ion complexes has been reported. These involve complexation of alkali and alkaline earth metal ions ${ }^{5}$ and various transition metal ions ${ }^{6,7}$ with diacetamide as well as a chain polymer analogue formed by N, N, N', N'-tetra-acetyl-1, 4,-diaminobutane with selected first row transition metal ions. ${ }^{8}$ Three reports ${ }^{9-11}$ of complexes formed by simple acyclic imide anions with transition metal ions have appeared, but to our knowledge no complexes involving transition metal ions with a simple neutral imide ligand of the form $\mathrm{RC}(\mathrm{O}) \mathrm{N}(\mathrm{H}) \mathrm{C}(\mathrm{O}) \mathrm{R}^{\prime}$ where $\mathrm{R}$ is thiophene have been reported. It was thus of interest to determine whether the imide group in both methyl-2- and methyl-3-thienyl imides would chelate metal ions. If this could be demonstrated, our long term interest would be to polymerize the 3-substituted thiophene or incorporate the methyl-2thienylimide and methyl-3-thienylimide monomer in a conducting polymeric material. These polymers could serve as metal-ion uptake and release materials which might be directed by an electrochemical signal (scheme 2). Such chemistry could have potential applications in environmental remediation ${ }^{12}$, charge storage devices ${ }^{13}$, and biochemical systems ${ }^{14}$.

Since the starting material, 2-thiophenecarboxamide, is readily available, methyl-2thienylimide was used as the preliminary basis for our studies (scheme 3), and most of our current work has been carried out using this ligand as a test case recognizing that similar chemistry would most probably occur for the methyl-3-thienylimide. In this paper we report on the successful complexation of $\mathrm{Mn}^{2+}, \mathrm{Co}^{2+}$, and $\mathrm{Ni}^{2+}$ by methyl-2-thienylimide and the complexation of $\mathrm{Co}^{2+}$ by methyl-3-thienylimide demonstrating the feasibility of this approach. The single crystal X-ray structures as well as the infrared and visible spectra of the complexes are discussed.

(insert schemes 1, and 2 here) 


\section{Results and Discussion}

\subsection{Synthesis.}

Methyl-2-thienylimide (L1)was synthesized initially in a yield of almost $50 \%$ by microwave irradiation of the reactants for three minutes. The previously reported method for the synthesis of methyl-3-thienylimide (L2) gave a better yield of methyl-2-thienylimide $(68 \%)^{1}$ but required two hours of reflux. Methyl-2-thienylimide had been previously synthesized ${ }^{15,16}$, but the structure had not been determined. Formation of the complexes resulted upon mixing solutions of the metal perchlorate with those of the ligands (scheme 4). In some cases slow evaporation of the solvent was necessary to grow crystals suitable for x-ray analysis; in others, the crystals grew from the undisturbed solution. Some trials resulted in precipitation of powders.

\section{(insert schemes 3 \& 4 here)}

\subsection{Crystallography}

Both ligands $\mathbf{L} 1$ and $\mathbf{L} 2$ form monoclinic crystals in space group P2 ${ }_{1} /$ c (\#14). Both molecules crystallize in the cis-trans configuration (with respect to the NH function) with the formation of intermolecular hydrogen-bonds through the $\mathrm{N}-\mathrm{H}$ hydrogen atom on one molecule and the carbonyl oxygen atom adjacent to the methyl group on another molecule to form dimers. Such dimers have been observed in other acyclic imides ${ }^{17}$. Since the structure of $\mathbf{L} \mathbf{2}$ has been described previously, L2 will not be discussed here but Fig.1 shows the thermal ellipsoid plots for both molecules. Selected data for $\mathbf{L 1}$ and complexes 1-4 are presented in Tables 1-3. Molecular plots and packing diagrams are presented in Figs. 1-5. The $\mathrm{C}=\mathrm{O}$ bond distances in $\mathbf{L 1}$ are 1.218(1) and 1.222(1) $\AA$, the C-N distances are 1.384(2) and 1.393(1) $\AA$, and the C-C distances are 1.494(2) $\AA$ (methyl) and 1.470(2) $\AA$ (2-thienyl). L2 has similar bond distances ${ }^{1}$. Single crystal X-ray structures of diacetamide ${ }^{18,19}$, acetylbenzamide ${ }^{20}$, isobutyrylbenzamide ${ }^{21}$, dibenzamide $^{22}$, and dipivilamide ${ }^{23}$ have been reported and the interatomic distances listed above are similar with allowance for differences in the substituents.

\section{(insert tables 1, 2, and 3 here)}

\section{(insert Fig. 1 here)}

Complex 1 crystallizes in the triclinic system, space group P-1 (\#2) with one $\left[\mathrm{Ni}\left(\mathrm{C}_{7} \mathrm{H}_{7} \mathrm{NO}_{2} \mathrm{~S}\right)_{2}\left(\mathrm{H}_{2} \mathrm{O}\right)_{2}\right]^{2+}$ cation and 2 perchlorate ions per asymmetric unit. The bidentate ligands of the cation occupy equatorial positions, with the thiophene rings cis to each other, and each water is bonded to the metal ion through oxygen. The nitrogen atom is protonated, and the neutral ligand undergoes hydrogen bonding through the $\mathrm{N}-\mathrm{H}$ hydrogen atom with two perchlorate anions. Two water molecules are trans to each other in the apical positions and each water is also hydrogen-bonded to two perchlorate ions. One of the perchlorate ions is disordered with a single (fully occupied) oxygen atom serving as a pivot point for two alternate $(83 / 17 \%$ ) orientations of $\mathrm{a} \mathrm{ClO}_{3}$ group. The average $\mathrm{O}=\mathrm{C}$ bond distance for 1 is $1.234(2,4,7,4) \AA$ (the four numbers in parentheses are the RMS value of the ESD for an individual datum, the mean and maximum deviations and the number of individual values used to determine the average value). This bond lengthening is expected for coordination of the metal ion by oxygen. The average C-N 
bond length is $1.380(2,6,13,4) \AA$ while that for the ligand is $1.389(2,4,5.2) \AA$; the bond shortening would also be expected owing to greater delocalization over the -O-C-N-C-O- system. The carbonyl-carbon to methyl-carbon bond distances are essentially unchanged within the measurement error limits, but the carbonyl-carbon to thiophene-carbon distance decreases from that in the free ligand $(1.470(2)$ to $1.455(3,1,1,2) \AA$ ) probably as a result of extended resonance over the $\mathrm{C}-\mathrm{C}$ bond in the complex. Bond lengths in acetylbenzamide ${ }^{20}$ as a ligand compare well with methyl-2-thienylimide, but the only crystal structure of a metal ion complex (CCDC and Scifinder) was that of a tetrahedral metal silver (I) complex containing one acetylbenzamide ligand and two phosphine ligands which is not relevant for a direct structural comparison. ${ }^{24} \mathrm{~A}$ low precision crystal structure of diacetamide is available, but only the crystal structure of its complex with $\mathrm{Ba}^{2+}$ has been reported. ${ }^{5 \mathrm{~d}, \mathrm{e}}$ The complex involved five bidentate diacetamide molecules and the precision was such that bond distance changes between the ligand and the complex were almost negligible. A useful comparison is with N, N, N', N'-tetra-acetyl-1, 4,diaminobutane, which has two diacetamide groups connected by a butane chain via the nitrogen atoms ${ }^{8,25}$. For example its complex with $\mathrm{Cu}^{2+}$ shows the following data. Free ligand: $\mathrm{C}=\mathrm{O}$, 1.217(2), 1.199 (2); C-N, 1.399(2), 1.405(2); C-C, 1.488(2), 1.499(2). Cu Complex: C=O, 1.228(3), 1.229(3); C-N, 1.387(3), 1.390(3); C-C, 1.493(4), 1.491(3) А ${ }^{25}$.

The average metal- $\mathrm{O}$ bonds for the $\mathrm{O}=\mathrm{C}$ and water oxygens are $2.017(1,8,15,4)$ and $2.058(2,6,7,2) \AA$, respectively. The "bite" angles subtended at the metal center in $\mathbf{1}$ by the ligand oxygens are $86.90(6)$ and $86.18(6)^{\circ}$, and the water molecules in the apical positions are nearly linear and perpendicular to the equatorial plane $\left(\mathrm{O}_{\mathrm{ap}}-\mathrm{Ni}-\mathrm{O}_{\mathrm{ap}}=177.02(7)^{\mathrm{o}}\right.$; average $\mathrm{O}_{\mathrm{ap}}-\mathrm{Ni}-\mathrm{O}_{\mathrm{eq}}$ angle $\left.=90.01(7)^{\circ}\right)$. The plane of one of the thiophene rings $(\mathrm{S} 1)$ is about $18.8(0.10)^{\circ}$ out of the mean equatorial plane (described by oxygen atoms $\mathrm{O} 1, \mathrm{O} 2, \mathrm{O} 3$ and $\mathrm{O} 4$ ) while the other (S2) is about $6.6(0.12)^{\mathrm{o}}$ out of the plane. The planar thiophene rings are skewed with respect to the $-\mathrm{O}-$ $\mathrm{C}-\mathrm{N}-\mathrm{C}-\mathrm{O}-$ plane by $20.51^{\circ}$ (S1) and $2.48^{\circ}$ (S2), respectively. The planes of the $-\mathrm{C}-\mathrm{N}-\mathrm{C}-\mathrm{systems}$ are tilted by $2.1(0.3)^{\circ}$ and $6.6(0.3)^{\circ}$, respectively, relative to the mean equatorial plane. The packing is a 2D network along the $\left(\begin{array}{lll}1 & 0 & 1\end{array}\right)$ plane resulting from hydrogen bonding through the perchlorate ions.

\section{(insert fig. 2 here)}

Complex 2 crystallizes in a monoclinic lattice in space group $\mathrm{P} 22_{1} / \mathrm{n}$ (\# 14) with one $\left[\mathrm{Mn}\left(\mathrm{C}_{7} \mathrm{H}_{7} \mathrm{NO}_{2} \mathrm{~S}\right)_{3}\left(\mathrm{H}_{2} \mathrm{O}\right)\right]^{2+}$ cation and 2 perchlorate anions per asymmetric unit. The $\mathrm{Mn}$ (II) is 7 coordinate with three bidentate ligands and a water molecule. The coordination geometry is a distorted pentagonal bipyramid of oxygen atoms with the water oxygen $(\mathrm{O} 7)$ and one of the ligand oxygen (O5) atoms occupying apical positions where the O-Mn-O angle is somewhat distorted from linearity $\left(169.76(6)^{\circ}\right)$. The average $\mathrm{C}=\mathrm{O}$ bond length is $1.223(2,6,12,6) \AA$ with the longest bond $(1.235(2) \AA)$ trans to the coordinated water molecule. The $-\mathrm{C}-\mathrm{N}-\mathrm{C}$ - bond system (average C-N bond $1.380(3,8,9,6) \AA$ ) is similar to those observed in complex 1 . The average metal-O bonds for the $\mathrm{O}=\mathrm{C}$ and water oxygens are $2.243(2,38,79,6)$ and $2.149(2) \AA$, respectively. The three bidentate ligands have the sulfur atoms of the thiophene rings syn to each other and the rings are twisted out of the plane defined by the-O-C-N-C-O- bond system by $11.08^{\circ}(\mathrm{S} 1), 14.27^{\circ}$ (S2), and $11.82^{\circ}$ (S3). A 2D network is created by hydrogen-bonding involving the perchlorate ions with $\mathrm{N}-\mathrm{H}$ groups from neighboring imide complexes as well as hydrogen bonding involving the coordinated water molecule in the complex, resulting in the formation of an infinite chain in the (1 $0-1)$ plane. 
A seven coordinate complex (aqua-tris-(diphenylpropanedionato)holmium has been reported by Zalkin, et al. ${ }^{26}$; the propanedionato portion is analogous to the imide function, but the coordination geometry is described as a highly distorted monocapped octahedron. However, an anionic oxalate-tantalum complex reported by Andros, et al. ${ }^{27}$ is described as a pentagonal bipyramid of seven oxygen atoms, six from the oxalate ligands and one from water with apical/equatorial O-Ta-O angles ranging from 102.76 to $74.86^{\circ}$. Complex 2 has similar angles ranging from 108.07(6) to 75.52(5) . A binuclear manganese complex of carbodihydrazide (CHZ), with two nitrogen and three oxygen donors from two $\mathrm{CHZ}$ ligands, one oxygen atom from sulfate which bridges the next binuclear unit, and one oxygen atom from water has been reported by Chen, et al. ${ }^{28}$ to form a distorted pentagonal bipyramid also, but the complex is less distorted than 2 with the O-Mn-O angles ranging from 95.56 to $80.66^{\circ}$ owing to the rigidity of the system. Cotton ${ }^{29}$ has pointed out that conformational interconversions do not require large angle changes and the structure observed may be a result of ligand steric constraints and/or crystal packing.

\section{(insert fig. 3 here)}

Complex 3 crystallizes in a monoclinic lattice in space group $\mathrm{P} 2{ }_{1} / \mathrm{n}$ (\#14) with the formula $\left[\mathrm{Co}\left(\mathrm{C}_{7} \mathrm{H}_{7} \mathrm{NO}_{2} \mathrm{~S}\right)_{2}\left(\mathrm{H}_{2} \mathrm{O}\right)_{2}\right]\left(\mathrm{ClO}_{4}\right)_{2}-1.1 \mathrm{H}_{2} \mathrm{O}$. The coordination sphere of the cobalt ion consists of an octahedron of oxygen atoms with the water molecules trans to each other in the apical positions and the bidentate ligands in the equatorial plane. The average metal-O bonds for the $\mathrm{O}=\mathrm{C}$ and water oxygens are $2.072(2,20,31,4)$ and $2.078(2,6,6,2) \AA$, respectively. The "bite" angles subtended at the metal center in 3 by the ligand oxygens are 83.61(7) and 83.05(7) ${ }^{\circ}$, smaller than those observed for the Ni complex, 1 . The water molecules in the apical positions are nearly linear and perpendicular to the equatorial plane $\left(\mathrm{O}_{\mathrm{ap}}-\mathrm{Co}-\mathrm{O}_{\mathrm{ap}}=173.39(8)^{\mathrm{o}}\right.$; average $\mathrm{O}_{\mathrm{ap}}-\mathrm{Co}-\mathrm{O}_{\mathrm{eq}}$ angle $\left.=90.06(8)^{\circ}\right)$. As in complex 1, the thiophene rings are cis. However, in one structural determination of $\mathbf{3}$ which contained ethyl acetate in the lattice, the rings were trans suggesting that the energy difference between the isomers is small. (Although the cis structure refined well, the trans structure could not be refined to the degree deemed acceptable). The plane of one of the thiophene rings (S1) is about $28.8^{\circ}$ out of the mean equatorial plane (described by oxygen atoms $\mathrm{O} 1, \mathrm{O} 2, \mathrm{O} 3$ and $\mathrm{O} 4)$ while the other (S2) is about $26.3^{\circ}$ out of the plane with the thiophene rings on opposite sides of the 4 equatorial oxygens and significantly more distorted than observed in 1. The planar thiophene rings are skewed with respect to the $-\mathrm{O}-\mathrm{C}-\mathrm{N}-\mathrm{C}-\mathrm{O}-$ planes by $18.4^{\circ}(\mathrm{S} 1)$ and $10.4^{\circ}(\mathrm{S} 2)$, respectively. The planes of the $-\mathrm{C}-\mathrm{N}-\mathrm{C}$ - systems are also tilted significantly more than observed in $1\left(12.6^{\circ}\right.$ and $22.7^{\circ}$, respectively, in 3$)$ relative to the mean equatorial plane. The average $\mathrm{O}=\mathrm{C}$ bond distance for 3 is $1.237(3,2,3,4) \AA$, similar to that observed in complex $\mathbf{1}$, with comparable values $(1.377(3,8,13,4) \AA$ ) for the average C-N bond length. The average carbonyl-carbon to methyl-carbon and carbonyl-carbon to thiophene-carbon distances are $1.488(3,2,2,2)$ and $1.449(3,2,2,2) \AA$, respectively. Hydrogen atoms from the coordinated water molecules and the ligand $\mathrm{NH}$ groups form an extensive $2 \mathrm{D}$ network of hydrogen bonds, parallel to the $\left(\begin{array}{lll}0 & 1 & 0\end{array}\right)$ plane of the unit cell. Additional lattice water molecules are also involved in hydrogen-bonding with one of the carbonyl oxygens $(\mathrm{O} 4)$ or perchlorate oxygens.

\section{(insert fig. 4 here)}

Complex 4 crystallizes in a triclinic lattice in space group P-1 (\#2) with $1 / 2$ of the formula $\left[\mathrm{Co}\left(\mathrm{C}_{7} \mathrm{H}_{7} \mathrm{NO}_{2} \mathrm{~S}\right)_{3}(\mathrm{H} 2 \mathrm{O})_{2}\right]\left(\mathrm{ClO}_{4}\right)_{2}-2 \mathrm{C}_{4} \mathrm{H}_{8} \mathrm{O}_{2}$ per asymmetric unit. In contrast to complex $\mathbf{1}$, the 
thiophene rings are trans since the cobalt occupies a crystallographic inversion center. The average $\mathrm{C}=\mathrm{O}$ bond distance has increased over those in the free ligand (1.230(3) $\AA$ in 4$)$ and the average C-N-C- bond distances have decreased to 1.374(3) $\AA$ as expected. The presence of two molecules of ethyl acetate in the unit cell may have an effect on the orientation of the rings (see $\mathbf{3}$ above) as well as the increase in planarity of the coordinated ligand. The plane of the thiophene ring (S1) is about $12.2^{\circ}$ out of the mean equatorial plane (described by the $4 \mathrm{C}=\mathrm{O}$ oxygen atoms). The planar thiophene rings are tilted with respect to the $-\mathrm{O}-\mathrm{C}-\mathrm{N}-\mathrm{C}-\mathrm{O}-$ planes by $12.6^{\circ}$. The planes of the $-\mathrm{C}-\mathrm{N}-\mathrm{C}$ - systems are also tilted significantly less than observed in $\mathbf{3}\left(4.8^{\circ}\right.$ in $\left.\mathbf{4}\right)$ relative to the mean equatorial plane. The ethyl acetate of crystallization is hydrogen-bonded via the oxygen atom to the hydrogen atom on the apical water molecules and appears to be held quite tightly in the lattice by hydrogen-bonding (O...O contact, 2.657(3) ̊, D-H...A angle, 171(4) ${ }^{\circ}$ ); pumping on the crystals, prior to sending a sample for analysis, removed all but $20 \%$ as indicated by the analytical results. Perchlorate also forms hydrogen bonds involving both the second hydrogen atom of the apical water molecule and the imide hydrogen atom on the coordinated ligand in an adjacent cation. The hydrogen-bonding results in a chain structure in the

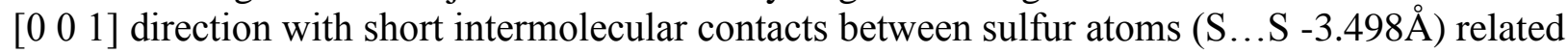
by the inversion center at $(1 / 2,1,0)$ in the unit cell.

\section{(insert fig. 5 here)}

\subsection{Spectroscopy.}

Before obtaining infrared spectra of the powders on crushed crystals, powder diffraction data were obtained to ensure that the bulk material represented the same structure as that obtained from the single crystal structure determination. Two ligand $\mathrm{N}-\mathrm{H}$ stretching bands appeared of medium intensity $\left(\mathbf{L 1}: 3275,3095 \mathrm{~cm}^{-1}\right.$; L2: 3286, $\left.3098 \mathrm{~cm}^{-1}\right)$ which, due to hydrogen-bonding, are lower than those generally observed; the bands are split as is the case with the diacylamides ${ }^{7}$.The corresponding bands for the complexes were observed as very weak features (1: 3357, 3107; 2: 3321, 3107; 3: 3334, $3108 \mathrm{~cm}^{-1}$ ). Other weak -O-H and broad stretching bands for the apical water molecules which are hydrogen bonded appeared above $3400 \mathrm{~cm}^{-1}$. Very weak features above $3000 \mathrm{~cm}^{-1}$ are associated with $\mathrm{C}-\mathrm{H}$ ring stretching while those near $3000 \mathrm{~cm}^{-1}$ are associated with $\mathrm{C}-\mathrm{H}$ stretching vibrations of the methyl group which have been found to be very weak in the diacetamide complexes ${ }^{7}$. The complexes exhibited two strong imide 1 bands in the carbonyl region (1: 1691, 1647; 2:1688, 1647; 3:1709, $1643 \mathrm{~cm}^{-1}$ ) which were comparable in frequency to the single broad vibration (with shoulders) observed for the parent ligands (L1: 1674; L2: $1690 \mathrm{~cm}^{-1}$ ). The free ligand spectra were similar to that for diacetamide $^{30}$ which has a single strong $\mathrm{C}=\mathrm{O}$ band at higher frequency $\left(1735 \mathrm{~cm}^{-1}\right)$ and a weak band at $1690 \mathrm{~cm}^{-1}$; it was noted that the symmetric and antisymmetric modes are often in the ratio of about 50:1 for diacylamides ${ }^{17}$. In the case of unsymmetrical diacylamides, only one band may be observed ${ }^{30}$. Upon complex formation, it would be expected that the C-O vibrations would be lower than those of the parent ligands owing to longer bond lengths resulting from a reduced bond order. This was not observed in the IR spectra in some instances but was certainly indicated by bond distances obtained from the crystal structure; this infrared result has been observed for a benzoylurea complex of samarium ${ }^{31}$. A possible explanation may be that, in the ligands, the intermolecular hydrogen-bonding between the carbonyl group attached to methyl and the N-H bond of an adjacent molecule, as observed in the crystal structure reported here, could lower the $\mathrm{C}=\mathrm{O}$ frequency significantly as could delocalization of electron density at the 
carbonyl group attached to thiophene via conjugation with the ring. Very strong perchlorate vibrations were observed in the vicinity of $1070 \mathrm{~cm}^{-1}$ for the complexes ${ }^{32}$. Absorptions at 1522 $\mathrm{cm}^{-1}$ for $\mathbf{L} \mathbf{1}$ and $1514 \mathrm{~cm}^{-1}$ for $\mathbf{L} \mathbf{2}$ (imide II band) are primarily due to $-\mathrm{C}-\mathrm{N}-\mathrm{C}$ - stretching with a contribution from the N-H in-plane deformation. These bands are lowered only slightly in the complexes as noted by Kraihanzel ${ }^{7}$. The imide III band consists mainly of the N-H deformation with a minor contribution from the $-\mathrm{C}-\mathrm{N}-\mathrm{C}$ - mode and occurs near $1259(\mathbf{L 1})$ and $1255(\mathbf{L 2}) \mathrm{cm}^{-}$ ${ }^{1}$; the bands are shifted to slightly lower frequencies (1: 1255; $\left.2: 1255 ; 3: 1250\right)$, but, given the resolution of the spectrophotometer $\left(4 \mathrm{~cm}^{-1}\right)$, they are not significantly different. One would have expected a rise in frequency due to bonding of the carbonyl groups to the metal ion which would increase delocalization in the-C-N-C- bond system. However, hydrogen bonding which occurs to different extents both in the parent ligands and in the complexes may be responsible for this observation. It is worth noting that the parent ligands are in the cis-trans $(\mathrm{C}=\mathrm{O}$ to $\mathrm{NH})$ configuration while in the complexes they are necessarily in the trans-trans configuration which complicates the assignments. Spectra for 1-4 are given in Table 4.

\section{(insert Table 4 here)}

The visible spectra for $\mathbf{1}, \mathbf{3}$, and $\mathbf{4}$ in nitromethane gave spectra similar to those reported for complexes of diacetamide ${ }^{7}$ in acetone. It was reported that the diacetamide complexes were unstable in nitromethane ${ }^{7}$, but we found that only a small change occurred over a period of two days for the Co-thienylimide complexes reported here. As a precaution, the spectrum of a sample of pure $\mathrm{Co}\left(\mathrm{ClO}_{4}\right)_{2} \cdot 6 \mathrm{H}_{2} \mathrm{O}$ was recorded and found to absorb at $503 \mathrm{~nm}$, close to bands reported for this substance in a variety of solvents ${ }^{33}$ and significantly different from those of $\mathbf{3}$ and $\mathbf{4}$. The band at $382 \mathrm{~nm}$ for the nickel complex is almost at the cut-off point for nitromethane $(380 \mathrm{~nm})$; thus, $\lambda_{\max }$ for this band should be taken as an estimate. A spectrum was acquired immediately after mixing the complex with methanol and $\lambda_{\max }$ appeared at $387 \mathrm{~nm}$. This value is close to that reported $^{7}$ for a trisdiacetamide complex. ${ }^{5}$

\section{Experimental}

\subsection{Materials and Instrumentation}

The following products were obtained commercially: acetonitrile, ethyl acetate, hexanes (all HPLC), 2-thiophenecarboxamide (99\%), silica (0.035-0.07 mm, $6 \mathrm{~nm}$ pore), sea sand (washed), Acros. Acetic anhydride (98\%), methyl alcohol (HPLC), Aldrich. Methylene chloride (ACS), nitromethane (spectral grade) Fisher. Chloroform (D-99.8 \%), Cambridge Isotope Laboratories, Inc. Tetra-n-butylammonium hexafluorophosphate, Oakwood Products, Inc. Nickel (II) perchlorate hexahydrate, cobalt (II) perchlorate hexahydrate, manganese (II) perchlorate hexahydrate, Alfa Aesar. Methyl-3-thienylimide was prepared by a method reported for general imide synthesis ${ }^{34}$ and utilized by us previously ${ }^{1}$.

IR transmittance spectra were obtained using a Perkin Elmer Spectrum 100 ATR-FT-IR Spectrometer. Visible spectra were recorded on $10^{-2} \mathrm{M}$ samples in spectral grade nitromethane (1 cm Starna quartz matched cells) on an HP Agilent 8453 Diode Array UV-Visible Spectrophotometer. Microwave irradiation was carried out in a GlassChem 20 Vessel using a CEM MARS Synthesis System. Elemental Analyses were carried out by Atlantic Microlabs, Inc. Single crystal X-ray diffraction data were collected on a Bruker SMART APEX CCD area 
detection system at $123 \mathrm{~K}(\mathbf{3})$, or $193 \mathrm{~K}(\mathbf{L 1}, \mathbf{1}, \mathbf{2}, \mathbf{4})$ using Mo K $\alpha$ radiation $(\lambda=0.71073 \AA)$ and Bruker SMART software. Data were corrected for variable scaling and absorption effects using the multi-scan(SADABS) method (Sheldrick). All of the structures were solved and refined using Bruker SHELXTL or APEX2 software (Bruker AXS Inc., Madison, WI). Crystallographic data for $\mathbf{L 1}$ and 1, 2, 3, and 4 have been deposited at the Cambridge Crystallographic Data Centre (CCDC 1487444-1487448). These data can be obtained free of charge via the internet at www.ccdc.cam.ac.uk/data_request/cif, by email at data_request@ccdc.cam.ac.uk. or by contacting the Cambridge Crystallographic Data Centre, 12 Union Road, Cambridge CB2 1EZ, UK; fax: +44(0)1223-336033. Analysis of the structures was carried out using PLATON ( Spek $\left.^{35}\right)$ and Mercury 3.3 software (CSD Version 5.6, July, 2015).

\subsection{Synthesis}

3.2.1 methyl-2-thienylimide L1: 2-Thiophenecarboxamide (1.00 g, $7.86 \mathrm{mmol}$ ), acetic anhydride (23.6 mmol, $2.23 \mathrm{~mL})$, a catalytic amount of conc. sulfuric acid, and a stir bar were placed into a dry GlassChem 20 Vessel. The mixture underwent microwave irradiation for 3 min. at $400 \mathrm{~W}$ according to a general procedure for $\mathrm{N}$-acylation of amides which was adapted from Lee et al. ${ }^{36}$ The resulting caramel colored solution was cooled and quenched with ice water. The product mixture was extracted with dichloromethane several times. The organic layer was treated with saturated sodium bicarbonate, dried, filtered with magnesium sulfate, and rotary evaporated to dryness. The crude product was purified by column chromatography (40:60 ethyl acetate/hexanes) resulting in a $49 \%$ isolated yield. FTIR-ATR $\left(\mathrm{cm}^{-1}\right): 3360 \mathrm{vw}, 3275 \mathrm{~m}, 3163$ vw, 3110 w, 3095 w, 1703 m, 1674 vs, 1522 m,1471 m, 1408 m,1377 m, 1353 m,1288 s, 1259 s, 1238 vs, 1092 m, 1073 m, 1043 w, 1015 m, 920 w, 870 w, 860 m, 842 w, 820 m, 777 m, 756 w,730 s, 666, w. Anal. L1 Calcd. (\%): $\mathrm{C}_{4} \mathrm{H}_{3} \mathrm{SC}(\mathrm{O}) \mathrm{N}(\mathrm{H}) \mathrm{C}(\mathrm{O}) \mathrm{CH}_{3} \mathrm{C}, 49.69 ; \mathrm{H}, 4.18$. Found: $\mathrm{C}$, 49.59; H, 4.17.

A second method ${ }^{1,34}$ entailed adding 2-thiophenecarboxamide (3.00 g, $\left.23.6 \mathrm{mmol}\right)$, acetic anhydride $(23.5 \mathrm{mmol}, 2.22 \mathrm{~mL})$, and conc. sulfuric acid $(48.8 \mu \mathrm{L})$ to a dry three-neck $50-\mathrm{mL}$ round-bottom flask equipped with a stir bar, an addition funnel, a condenser, and an argon line. The reaction mixture was heated to reflux under argon $\left(144^{\circ} \mathrm{C}\right.$ pot temperature) for $2 \mathrm{hrs}$. The resulting brown solution was worked up by the same procedure described above resulting in a $68 \%$ isolated yield.

3.2.2 methyl-3-thienylimide L2: Methyl-3-thienylimide was prepared from 3thiophenecarboxamide and acetic anhydride as described previously. ${ }^{1}$

\subsection{3 diaqua-bis-(methyl-2-thienylimide)nickel (II) perchlorate (1). The general} procedure is illustrated for (1) in scheme 4. A solution of nickel (II) perchlorate hexahydrate $(0.108 \mathrm{~g}, 0.296 \mathrm{mmol})$ in $300 \mu \mathrm{L}$ of ethyl acetate was added to a solution of methyl-2thienylimide $(0.100 \mathrm{~g}, 0.592 \mathrm{mmol})$ in $600 \mu \mathrm{L}$ of ethyl acetate at a temperature of $60^{\circ} \mathrm{C}$ and slowly cooled. Rectangular, aqua blue crystals formed after several days. Visible spectrum: 382 $\mathrm{nm}$ (nitromethane) $387 \mathrm{~nm}$ (methanol); FTIR-ATR $\left(\mathrm{cm}^{-1}\right)$ : $3327 \mathrm{vw}, 3263 \mathrm{vw}, 3107 \mathrm{vw}, 1691 \mathrm{~s}$, 1647 s, 1517 w sh,1481 s,1412 m,1377 vvw, 1358 ms, 1318 vw, 1255 s, 1238 vs, 1069 vs, 948 vw, 932 vw, 868 w, 816 w,733 s, 679 vw. Anal. (1) Calcd. Ni(2-MTI $)_{2}\left(\mathrm{H}_{2} \mathrm{O}\right)_{2}\left(\mathrm{ClO}_{4}\right)_{2}(\%): \mathrm{C}, 26.6 ; \mathrm{H}$, 2.87. Found: $26.63,2.84$ 
3.2.4 aqua-tris-(methyl-2-thienylimide)manganese (II) perchlorate (2). Manganese (II) perchlorate hexahydrate $(0.642 \mathrm{~g}, 0.177 \mathrm{mmol})$, methyl-2-thienylimide $(0.060 \mathrm{~g}, 0.36 \mathrm{mmol})$, ethyl acetate solvent. FTIR-ATR $\left(\mathrm{cm}^{-1}\right)$ : $3334 \mathrm{w}, 3108 \mathrm{w}, 1709 \mathrm{vs}, 1643 \mathrm{vs}, 1519 \mathrm{w}$ sh,1475 s, $1411 \mathrm{~m}, 1381 \mathrm{vw}, 1358 \mathrm{~ms}, 1306 \mathrm{w}, 1250 \mathrm{~s}, 1221 \mathrm{vs}, 1070 \mathrm{vs}, 945 \mathrm{w}, 932 \mathrm{vvw}, 868 \mathrm{w}, 807 \mathrm{w}, 738$ s, 674 vw. Anal. (3) Calcd. $\mathrm{Mn}(2-\mathrm{MTI})_{3}\left(\mathrm{H}_{2} \mathrm{O}\right)\left(\mathrm{ClO}_{4}\right)_{2}(\%) \mathrm{C}, 32.40 ; \mathrm{H}, 2.97$. Found: 32.14, 2.90.

\subsection{5 diaqua-bis-(methyl-2-thienylimide)cobalt (II) perchlorate (3). Cobalt (II)}

perchlorate hexahydrate $(0.108 \mathrm{~g}, 0.295 \mathrm{mmol})$, methyl-2-thienylimide $(0.100 \mathrm{~g}, 0.592 \mathrm{mmol})$, ethyl acetate solvent. Visible spectrum: $510 \mathrm{~nm}$ (nitromethane); FTIR-ATR $\left(\mathrm{cm}^{-1}\right)$ : $3321 \mathrm{vw}$, $3106 \mathrm{vw}, 1688 \mathrm{~s}, 1647 \mathrm{~s}, 1518 \mathrm{w}$ sh,1478 s, 1412 m,1376 w,1358 m, 1317 w,1255 s,1236 vs, 1072 vs, 951 w, 932 w, 869 w, 814 w, 732 s, 679 vvw. Anal. (2) Calcd. for Co(2$\mathrm{MTI})_{2}\left(\mathrm{H}_{2} \mathrm{O}\right)_{2}\left(\mathrm{ClO}_{4}\right)_{2}(\%) \mathrm{C}, 27.81 ; \mathrm{H}, 3.00$. Found: 27.01, 2.87.

3.2.6 diaqua-bis-(methyl-3-thienylimide)cobalt (II) perchlorate (4). Separate solutions of cobalt (II) perchlorate hexahydrate and methyl-3-thienylimide in ethyl acetate were warmed to $50^{\circ} \mathrm{C}$. The cobalt solution was added to the imide using a heated pipette, forming a pink solution. The solution was concentrated by slow evaporation until pink crystals formed. Visible spectrum: $511 \mathrm{~nm}$ (nitromethane); FTIR-ATR: $3467 \mathrm{w}, 3339 \mathrm{w}, 3113 \mathrm{w}, 1695 \mathrm{~s}, 1655 \mathrm{~s}, 1513 \mathrm{~m}, 1470 \mathrm{~s}$, $1418 \mathrm{~m}, 1376$ w, 128 w, 1238 s, 1213 ms, 1058 vvs br, 951 w, 932 m, 892 m, 841 w, 817 m, 743 s, $699 \mathrm{~m}$ br, $619 \mathrm{~m}$. Anal. (4) Calcd. for $\mathrm{Co}(3-\mathrm{MTI})_{2}\left(\mathrm{H}_{2} \mathrm{O}\right)_{2}\left(\mathrm{ClO}_{4}\right)_{2} \cdot \mathrm{EtOAc}$ (\%). C, 30.01; H, 3.64. Found: C, 29.60; H, 3.48 .

\section{Conclusions.}

This work shows that it is possible for ligand $\mathbf{L} \mathbf{1}$ to form complexes with transition metal ions, $\mathrm{Ni}^{2+}, \mathrm{Mn}^{2+}$, and $\mathrm{Co}^{2+}$ and for $\mathbf{L} 2$ with $\mathrm{Co}^{2+}$. In the ligands, the carbonyl groups are cis/trans with respect to the $\mathrm{N}-\mathrm{H}$ group in the solid state but are necessarily trans-trans in the complex. The ligands are bidentate forming bonds to the metal ions through the imide oxygen atoms; the imide nitrogen atoms in the ligands are protonated. The cobalt and nickel complexes have two bidentate ligands in the equatorial positions and two water molecules in the apical positions while the manganese complex is seven coordinate with three bidentate ligands and one water molecule; the structure is best described as a highly distorted pentagonal bipyramid. In complexes $\mathbf{1}$ and $\mathbf{3}$, the thiophene ligands are cis to each other while in $\mathbf{4}$ they are trans. The observance of the trans form in a sample of $\mathbf{3}$ indicates that there is very little difference in energy between the two orientations. Significant hydrogen-bonding is present in all of the complexes leading to the formation of 2D networks in $\mathbf{1}$ and $\mathbf{3}$ and an infinite chain in $\mathbf{2}$.

Acknowledgements. This work was supported by a Camille and Henry Dreyfus Foundation Senior Scientist Mentor Award. RCG acknowledges support by a Wake Forest Undergraduate Research Fellowship for the Summer of 2012. The WFU X-ray Facility thanks the National Science Foundation (grant CHE-0234489) for funds to purchase the X-ray instrument and computers. 


\section{References}

1. Dai, J.; Day, C. S.; Noftle, R. E. Tetrahedron, 2003, 59, 9389-9397.

2. Garibay, S. J.; Stork, J. R.; Cohen, S. M. Prog. Inorg. Chem. 2009, 56, 335-378.

3. Wang, Y.-P.; Luo, R.-M.; Yuan, 1. J. Appl. Polym. Sci., 1997, 66, 755-760.

4. Cowan, M. G.; Brooker, S. Coord. Chem. Rev. 2012, 256, 2944-2971.

5. (a) Dippy, J. F. J.;Moss, V. J. Chem. Soc. 1952, 2205. (b) Ley, H.; Werner, F. Ber. 1913, 4040. (c) Raban, M.; Keintz, R. A.; Noe, E. A. Tet. Letters, 1979, 19, 16331636. (d) Gentile, P. S.; White, J.; Haddad, S. Inorg. Chim. Acta 1975, 13, 149-161. (e) Gentile, P. S.; Shankoff, T. A. J. Inorg. Nucl. Chem. 1963, 27, 2301-2309

6. Goodgame, M.; Hussain, I., Inorg. Chim. Acta. 1995, 229, 165-169

7. Kraihanzel, K. S.; Grenda, S. C. Inorg. Chem. 1965, 4, 1037-1042.

8. Goodgame, D. M. L.; Goodgame, M.; Grachvogel, D. A.; Hussain, I.; Williams, D. J. J.Organometal. Chem. 2000, 596, 16-21.

9. Kraihanzel, C. S.; Stehly, D. N. Inorg. Chem. 1967, 6, 277-280.

10. Stehly, D. N.; Kraihanzel, C. S. Inorg. Chem. 1968, 8, 470-474.

11. Hinze, A. G.; Groeneveld, W. L. Rec. Trav. Chim. 1969, 88, 1275-1283.

12. Geckeler, K. E. Pure Appl. Chem. 2001, 73, 129-136.

13. Nishihara, H.; Kanaizuka, K.; Nishimori, Y.; Yamanoi, Y. Coord. Chem. Rev. 2007, 251, 2674-2687.

14. Tusek-Bozic, Lj. Curr. Med. Chem. 2013, 20, 2096-2117.

15. Mohammadpoor-Baltork, L.; Tangestaninejad, S.; Moghadam, M.; Mirkhani, V.; NasrEsfahani, M. J. Iranian Chem. Soc. 2011, 8, 401-410.

16. Putokhin, N. I.; Egorova, V. S. Zh. Obsh. Khim. 1948, 18, 1876-72.

17. Etter, M. C.; Reutzal, S. M. J. Am. Chem. Soc.1991, 113, 2586-2598.

18. Matias, P. M.; Jeffrey, G. A.; Ruble, J. R. Acta Cryst. 1988, B44, 516-522.

19. Kuroda, Y.; Taira, Z.; Uno, T.; Osaki, k. Cryst. Struct. Comm. 1975, 4, 321324.

20. Etter, M. C.; Britton, D.; Reutzel, S. M. Acta Cryst. 1991, C47, 556-561.

21. Bates, R. B.; Janda, K. D.; Wright, M. E. Acta Cryst. 1983, C41, 263-264.

22. Mizrahi, V.; Niven, M. L. S. Afr. J. Chem. 1983, 36, 137-142.

23. Hvoslef, J.; Tracy, M. L.; Nash, C. P. Acta Cryst. 1986, C42, 353-360.

24. Tao, X.; Shen, K.-C.; Tang, Q.-Y.; Feng, M.; Fang, J-T.; Wang, Y.-L.; Shen, Y.-Z. Appl. Organometal. Chem. 2012, 26, 323-329.

25. Aakeroy, C. B.; Desper, J. Haque, N.; Hussain, I. Cryst. Eng. Commun. 2010, 12, 3218-3224.

26. Zalkin, A.; Templeton, D. H.; Karraker, D. G.; Inorg. Chem. 1968, 8, 2680-2684.

27. Andros, L.; Matkovic-Calogovic, D.; Planinic, P. Cryst. Eng. Commun. 2013, 15, 533-543.

28. Chen, H-Y.; Zhang, T-L.; Zhang, J-G.; Yu, K-B. Struct. Chem. 2005, 16, 657-663.

29. Cotton, F. A.; Legzdins, P. Inorg. Chem. 1968, 9, 1777-1783.

30. Uno, T.; Machida, K. Bull. Chem. Soc. Jpn. 1961, 34, 551-556.

31. Zhang, W.; Tan, w.; Liu, W. Polyhedron, 1992, 11, 1581-1585.

32. Nakamoto, K. Infrared and Raman Spectra of Inorganic and Coordination Compounds; Wiley: New York 1986; Pt. III, pp 251-253.

33. Abu-Eittah, R.; Arafa, G. J. Inorg. Nucl. Chem.1970, 32, 2721-2729.

34. Barburao, K.; Costello, A. M.; Petterson, R. C.; Sander, G. E. J. Chem. Soc.(C), 1968, 2779-2781

35. Spek, A. L. Acta Cryst. 2009 D65, 148-155.

36. Lee, J.; Hong, M.; Jung, Y.; Cho, E. J.; Rhee, H. Tetrahedron, 2012, 68, 2045-2051. 
List of captions:

(scheme 1)

Scheme 1. 2-Thienylacetylacetone and methyl-2thienylimide.

(scheme 2)

Scheme 2. Anticipated electrochemical uptake and release of metal ions.

(scheme 3)

Scheme 3. Synthesis of methyl-2-thienylimide (L1, top) and methyl-3-thienylimide, (L2, bottom).

(scheme 4)

Scheme 4. Formation of methyl-2-thienylimide (L1) complexes of (a.) $\mathrm{Ni}^{2+}$ and $\mathrm{Co}^{2+}$ (b.) $\mathrm{Mn}^{2+}$.

(Tables 1, 2, 3, 4)

no captions, titles included as part of tables

(figure 1)

Fig 1. Thermal ellipsoid plot (probability level 50\%) with the atom labeling scheme of (a.) L1 (b.) L2 showing dimeric structure due to hydrogen-bonding.

(figure 2)

Fig. 2. Thermal ellipsoid plot (probability level 50\%) with the atom labeling scheme of $\mathbf{1}$ and packing diagram of $\mathbf{1}$ along $a$ axis.

(figure 3)

Fig. 3. Thermal ellipsoid plot (probability level 50\%) with the atom labeling scheme of $\mathbf{2}$ and packing diagram of $\mathbf{2}$ along $a$ axis.

(figure 4)

Fig. 4. Thermal ellipsoid plot (probability level 50\%) with the atom labeling scheme of $\mathbf{3}$ and packing diagram of $\mathbf{3}$ along $b$ axis.

(figure 5)

Fig. 5. Thermal ellipsoid plot (probability level 50\%) with the atom labeling scheme of $\mathbf{4}$ and packing diagram of $\mathbf{4}$ along $b$ axis. 
(scheme 1)<smiles>CC(=O)CC(=O)c1cccs1</smiles>

2-thienylacetylacetone<smiles>CC(=O)NC(=O)c1cccs1</smiles>

methyl-2-thienylimide

(scheme 2)<smiles>CC(=O)NC(=O)c1cc(C(C)(C)C)sc1C(C)(C)C</smiles><smiles>CC(=O)NC(=O)c1cc(C(C)(C)C)sc1C(C)(C)C</smiles>

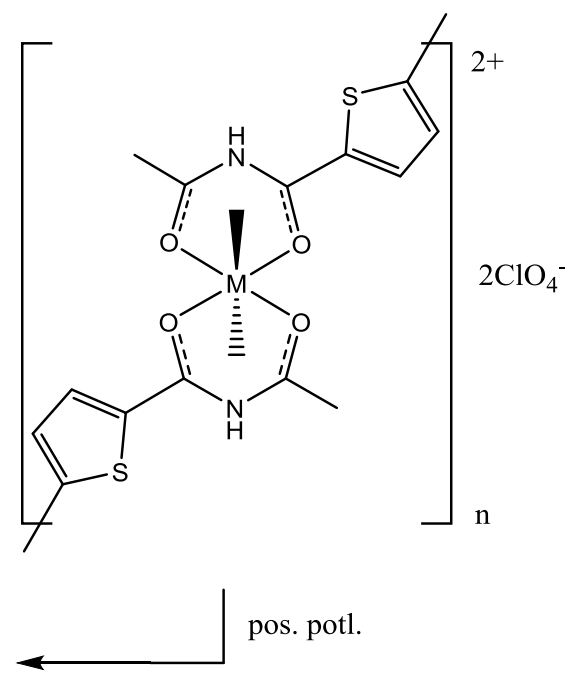

(scheme 3)<smiles>CC(=O)NC(=O)c1ccsc1C(=O)NC(C)=O</smiles> 
(scheme 4)

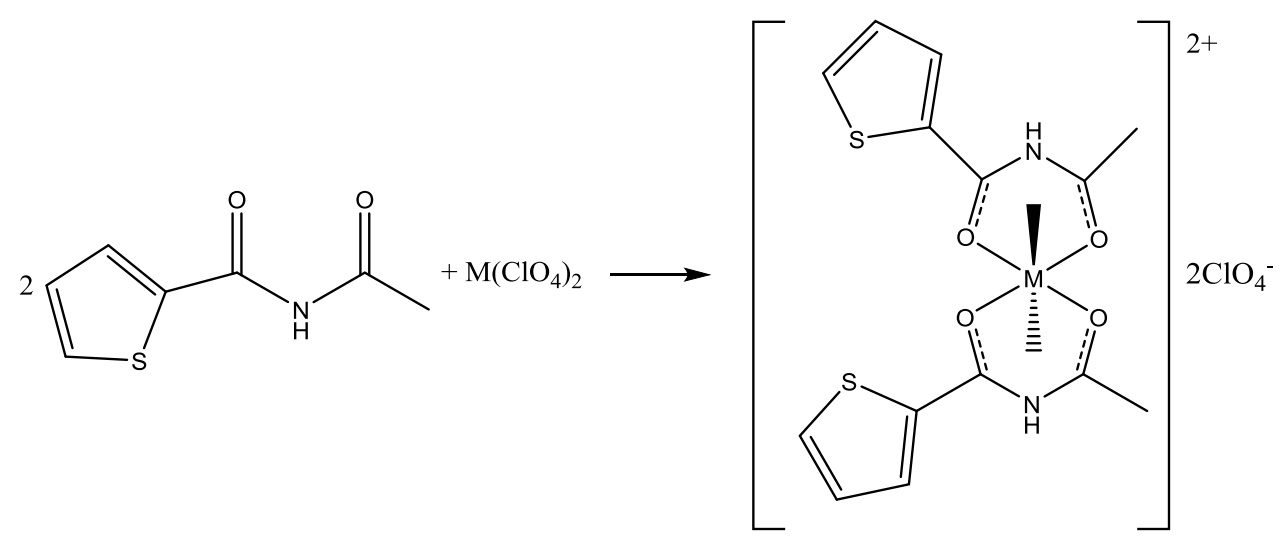


Table 1. Crystallographic Data for L1 and 1-4

\begin{tabular}{|c|c|c|c|c|c|}
\hline Compound & $\mathbf{L}_{1}$ & 1 & 3 & 4: with L2 ligand & 2 \\
\hline Empirical formula & $\mathrm{C}_{7} \mathrm{H}_{7} \mathrm{NO}_{2} \mathrm{~S}$ & $\mathrm{C}_{14} \mathrm{H}_{18} \mathrm{Cl} 2 \mathrm{~N}_{2} \mathrm{NiO}_{14} \mathrm{~S}_{2}$ & $\mathrm{C}_{14} \mathrm{H}_{20.2} \mathrm{~N}_{2} \mathrm{O}_{15.1} \mathrm{~S}_{2} \mathrm{Cl}_{2} \mathrm{Co}$ & $\mathrm{C}_{22} \mathrm{H}_{34} \mathrm{~N}_{2} \mathrm{O}_{18} \mathrm{~S}_{2} \mathrm{Cl}_{2} \mathrm{Co}$ & $\mathrm{C}_{21} \mathrm{H}_{23} \mathrm{~N}_{3} \mathrm{O}_{15} \mathrm{~S}_{3} \mathrm{Cl}_{2} \mathrm{Mn}$ \\
\hline Formula weight & 169.20 & 632.03 & 652.07 & 808.46 & 779.44 \\
\hline Temperature (K) & 193(2) & $193(2)$ & $123(2)$ & $193(2)$ & 193(2) \\
\hline Crystal system & Monoclinic & Triclinic & Monoclinic & Triclinic & Monoclinic \\
\hline Space group & $\mathrm{P} 2_{1} / \mathrm{c}$ (No. 14$)$ & P-1 (No. 2) & $\mathrm{P} 2{ }_{1} / \mathrm{n}$ (No. 14$)$ & P-1 (No. 2) & $\mathrm{P} 2{ }_{1} / \mathrm{n}$ (No. 14$)$ \\
\hline \multicolumn{6}{|l|}{ Unit cell dimensions } \\
\hline$a(\AA)$ & $5.307(1)$ & $10.2461(8)$ & 7.7791(9) & $8.142(2)$ & $9.4336(8)$ \\
\hline$b(\AA)$ & $6.553(1)$ & $11.2180(9)$ & $28.286(3)$ & $9.644(2)$ & $20.175(2)$ \\
\hline$c(\AA)$ & $21.483(5)$ & $11.5312(9)$ & $11.326(1)$ & $11.376(2)$ & $16.713(1)$ \\
\hline$\alpha\left(^{\circ}\right)$ & & $89.500(1)$ & & $96.348(2)$ & \\
\hline$\beta\left({ }^{\circ}\right)$ & $93.295(2)$ & $82.967(1)$ & $101.975(1)$ & $101.973(2)$ & $92.526(1)$ \\
\hline$\gamma\left({ }^{\circ}\right)$ & & $67.133(1)$ & & $99.621(2)$ & \\
\hline Volume $(\AA)^{3}$ & $745.9(3)$ & $1211.0(2)$ & $2438.0(5)$ & $851.7(3)$ & $3177.9(5)$ \\
\hline Z & 4 & 2 & 4 & 1 & 4 \\
\hline $\begin{array}{l}\text { Calculated density } \\
\left(\mathrm{g} / \mathrm{cm}^{3}\right)\end{array}$ & 1.507 & 1.733 & 1.777 & 1.576 & 1.629 \\
\hline $\begin{array}{l}\text { Absorption } \\
\text { coefficient }\left(\mathrm{mm}^{-1}\right)\end{array}$ & 0.376 & 1.265 & 1.170 & 0.860 & 0.853 \\
\hline $\mathrm{F}(000)$ & 352.0 & 644 & 1328.0 & 417. & 1588.0 \\
\hline Crystal size (mm) & $\begin{array}{l}0.28 \times 0.11 \times \\
0.096\end{array}$ & $0.32 \times 0.17 \times 0.16$ & $0.24 \times 0.11 \times 0.05$ & $0.10 \times 0.07 \times 0.04$ & $0.15 \times 0.15 \times 0.11$ \\
\hline 2 Theta range $\left({ }^{\circ}\right)$ & $7.6-60.34$ & $7.44-59.14$ & $7.10-60.09$ & $7.4-57.86$ & $7.44-60.06$ \\
\hline \multirow[t]{3}{*}{ Limiting indices } & $-7 \leq \mathrm{h} \leq 7$ & $-14 \leq \mathrm{h} \leq 14$ & $-10 \leq \mathrm{h} \leq 10$ & $-11 \leq \mathrm{h} \leq 11$ & $-13 \leq h \leq 13$ \\
\hline & $-9 \leq \mathrm{k} \leq 9$ & $-15 \leq \mathrm{k} \leq 15$ & $-39 \leq \mathrm{k} \leq 39$ & $-13 \leq \mathrm{k} \leq 13$ & $-28 \leq \mathrm{k} \leq 28$ \\
\hline & $-30 \leq 1 \leq 30$ & $-16 \leq 1 \leq 16$ & $-15 \leq 1 \leq 15$ & $-15 \leq 1 \leq 15$ & $-23 \leq 1 \leq 23$ \\
\hline $\begin{array}{l}\text { Reflections } \\
\text { collected/unique }\end{array}$ & $10516 / 2198$ & $17216 / 6698$ & $35407 / 7090$ & $11321 / 4431$ & $46034 / 9254$ \\
\hline $\mathrm{R}_{\text {int }}$ & 0.0222 & 0.0213 & 0.0395 & 0.0468 & 0.0437 \\
\hline $\begin{array}{l}\text { Absorption } \\
\text { correction, } \\
\quad \text { transmission range }\end{array}$ & $\begin{array}{l}0.6837 \text { and } \\
0.7460\end{array}$ & 0.6490 and 0.7460 & 0.6679 and 0.7462 & 0.6296 and 0.7458 & 0.8828 and 0.9120 \\
\hline Data/parameters & $2198 / 104$ & $6698 / 365$ & $7090 / 406$ & $4431 / 238$ & $9254 / 429$ \\
\hline Goodness-of-fit on $F^{2}$ & 1.068 & 1.054 & 1.021 & 1.193 & 1.023 \\
\hline \multicolumn{6}{|l|}{ Final $\mathrm{R}$ indices } \\
\hline$\left[F_{\mathrm{o}}>4 \sigma\left(F_{\mathrm{o}}\right)\right.$ data $]$ & $\mathrm{R}_{1}=0.0332$ & $\mathrm{R}_{1}=0.0410$ & $\mathrm{R}_{1}=0.0469$ & $\mathrm{R}_{1}=0.0536$ & $\mathrm{R}_{1}=0.0429$ \\
\hline [all data] & $\begin{array}{l}\mathbf{R}_{1}=0.0354 \\
w \mathbf{R}_{2}=0.0989\end{array}$ & $\begin{array}{l}\mathrm{R}_{1}=0.0472 \\
w \mathrm{R}_{2}=0.1175\end{array}$ & $\begin{array}{l}\mathrm{R}_{1}=0.0614 \\
w \mathrm{R}_{2}=0.1208\end{array}$ & $\begin{array}{l}\mathrm{R}_{1}=0.0709 \\
w \mathrm{R}_{2}=0.1444\end{array}$ & $\begin{array}{l}\mathrm{R}_{1}=0.0572 \\
w \mathrm{R}_{2}=0.1158\end{array}$ \\
\hline $\begin{array}{l}\text { Largest differential } \\
\text { peak and hole } \\
\left(\mathrm{e}^{-} / \AA^{3}\right)\end{array}$ & 0.44 and -0.17 & 0.74 and -0.76 & 1.33 and -0.50 & 0.68 and -0.44 & 0.65 and -0.42 \\
\hline $\begin{array}{l}\mathrm{R}_{1}=\Sigma|| \mathrm{F}_{\mathrm{o}}|-| \mathrm{F}_{\mathrm{c}}|| /\left|\mathrm{F}_{\mathrm{o}}\right| \\
\mathrm{wR}_{2}=\left\{\Sigma\left[\mathrm{w}\left(\mathrm{F}_{\mathrm{o}}^{2}-\mathrm{F}_{\mathrm{c}}^{2}\right)^{2}\right]\right. \\
\mathrm{Goof}^{2}=\left[\Sigma \mathrm{w}\left(\mathrm{F}_{\mathrm{o}}^{2}-\mathrm{F}_{\mathrm{c}}^{2}\right)^{2} /\right. \\
\mathrm{R}_{\text {int }}=\Sigma \mid \mathrm{F}_{\mathrm{o}}^{2}-\mathrm{F}_{\mathrm{o}}^{2}(\text { mean }\end{array}$ & $\begin{array}{l}\left.\Sigma\left[\mathrm{w}\left(\mathrm{F}_{\mathrm{o}}^{2}\right)^{2}\right]\right\}^{1 / 2} \\
\left.\left.\mathrm{~N}_{\mathrm{d}}-\mathrm{N}_{\mathrm{p}}\right)\right]^{1 / 2} \\
/ \Sigma \mathrm{F}_{\mathrm{o}}^{2}\end{array}$ & & & & \\
\hline
\end{tabular}




\section{(table 2)}

Table 2. Selected Bonds, Metal-Ligand Bond Distances $(\AA ̊)$ and Angles $\left({ }^{\circ}\right)$ for L1 and 1-4

\begin{tabular}{|c|c|c|c|c|c|}
\hline Compound & $\mathbf{L}_{1}$ & 1 & 3 & 4: with L2 ligand & 2 \\
\hline Formula & $\mathrm{C}_{7} \mathrm{H}_{7} \mathrm{NO}_{2} \mathrm{~S}$ & $\mathrm{C}_{14} \mathrm{H}_{18} \mathrm{Cl} 2 \mathrm{~N}_{2} \mathrm{NiO}_{14} \mathrm{~S}_{2}$ & $\mathrm{C}_{14} \mathrm{H}_{20.2} \mathrm{~N}_{2} \mathrm{O}_{15.1} \mathrm{~S}_{2} \mathrm{Cl}_{2} \mathrm{Co}$ & $\mathrm{C}_{22} \mathrm{H}_{34} \mathrm{~N}_{2} \mathrm{O}_{18} \mathrm{~S}_{2} \mathrm{Cl}_{2} \mathrm{Co}$ & $\mathrm{C}_{21} \mathrm{H}_{23} \mathrm{~N}_{3} \mathrm{O}_{15} \mathrm{~S}_{3} \mathrm{Cl}_{2} \mathrm{Mn}$ \\
\hline \multicolumn{6}{|l|}{ Bond $^{\mathrm{a}}$} \\
\hline $\mathrm{M}(1)-\mathrm{O}(1)$ & - & $2.003(1), 2.014(2)$ & $2.053(2), 2.050(2)$ & $2.064(2)$ & $\begin{array}{c}2.221(2), 2.260(1), \\
2.164(1)\end{array}$ \\
\hline $\mathrm{M}(1)-\mathrm{O}(2)$ & - & $2.019(1), 2.032(1)$ & $2.081(2), 2.103(2)$ & $2.067(2)$ & $\begin{array}{c}2.280(2), 2.230(1), \\
2.301(2)\end{array}$ \\
\hline $\mathrm{M}(1)-\mathrm{O}$ (water) & - & $2.051(2), 2.064(2)$ & $2.073(2), 2.084(2)$ & $2.046(2)$ & $2.149(2)$ \\
\hline $\mathrm{O}(1)=\mathrm{C}$ & $1.218(1)$ & $1.235(2), 1.231(2)$ & $1.240(3), 1.236(3)$ & $1.235(3)$ & $\begin{array}{c}1.228(2), 1.221(2), \\
1.235(2)\end{array}$ \\
\hline $\mathrm{O}(2)=\mathrm{C}$ & $1.222(1)$ & $1.241(2), 1.228(2)$ & $1.237(3), 1.235(3)$ & $1.225(3)$ & $\begin{array}{c}1.220(2), 1.219(2), \\
1.214(2)\end{array}$ \\
\hline $\mathrm{C}(1)-\mathrm{N}(1)$ & $1.393(1)$ & $1.384(3), 1.387(2)$ & $1.379(3), 1.390(3)$ & $1.369(3)$ & $\begin{array}{c}1.371(3), 1.388(3), \\
1.372(2)\end{array}$ \\
\hline $\mathrm{C}(6)-\mathrm{N}(1)$ & $1.384(2)$ & $1.367(2), 1.381(2)$ & $1.369(3), 1.370(3)$ & $1.379(3)$ & $\begin{array}{c}1.389(2), 1.374(3), \\
1.386(2)\end{array}$ \\
\hline C - C(ring) & $1.470(2)$ & $1.454(3), 1.456(3)$ & $1.451(3), 1.447(3)$ & $1.463(3)$ & $\begin{array}{c}1.456(3), 1.453(3), \\
1.455(3)\end{array}$ \\
\hline C - C(methyl) & $1.494(2)$ & $1.487(3), 1.493(3)$ & $1.490(3), 1.486(3)$ & $1.483(4)$ & $\begin{array}{c}1.500(3), 1.499(3), \\
1.494(3)\end{array}$ \\
\hline \multicolumn{6}{|l|}{ Bond angles } \\
\hline $\begin{array}{l}\text { Average O-M- } \\
\mathrm{O} \text { (water1 or 2) }\end{array}$ & - & $90.23(7) ; 89.78(7)$ & $\begin{array}{l}90.06(7) \\
90.07(8)\end{array}$ & $90.0(-)$ & $91.21(6)$ \\
\hline $\begin{array}{l}\mathrm{O} \text { (water1)-M- } \\
\mathrm{O} \text { (water2) }\end{array}$ & - & $177.02(7)$ & $173.39(8)$ & $180.0(-)$ & \\
\hline $\begin{array}{l}\text { O-M-O (ligand } \\
\text { "bite") }\end{array}$ & & $\begin{array}{l}\mathrm{L}_{1}=86.90(6) \\
\mathrm{L}_{2}=86.18(6)\end{array}$ & $\begin{array}{l}\mathrm{L}_{1}=83.61(7) \\
\mathrm{L}_{2}=83.05(7)\end{array}$ & $\mathrm{L}_{1}=83.42(7)$ & $\begin{array}{l}\mathrm{L}_{1}=73.00(5) \\
\mathrm{L}_{2}=73.78(5) \\
\mathrm{L}_{3}=75.52(5)\end{array}$ \\
\hline $\mathrm{C}-\mathrm{N}-\mathrm{C}$ & $127.9(1)$ & $\begin{array}{l}\mathrm{L}_{1}=127.6(2) \\
\mathrm{L}_{2}=126.8(2)\end{array}$ & $\begin{array}{l}\mathrm{L}_{1}=127.2(2) \\
\mathrm{L}_{2}=127.1(2)\end{array}$ & $\mathrm{L}_{1}=127.5(2)$ & $\begin{aligned} \mathrm{L}_{1} & =125.4(2) ; \\
\mathrm{L}_{2} & =125.5(2) ; \\
\mathrm{L}_{3} & =126.8(2)\end{aligned}$ \\
\hline
\end{tabular}

${ }^{a} \mathrm{O}(1)$ and $\mathrm{O}(2)$ are used to represent carbonyl oxygens for the carbonyls adjacent to the thienyl ring $(\mathrm{O}(1))$ and methyl group $(\mathrm{O}(2))$, respectively. For compounds 1, $\mathbf{2}$ and $\mathbf{3}$ which contain multiple crystallographically-independent ligands, chemically equivalent bond lengths and angles are grouped accordingly.

\section{(table 3)}

Table 3. Hydrogen Contacts ( $\mathrm{A})$ for $\mathrm{L1}$ and 1-4

\begin{tabular}{lccccc}
\multicolumn{1}{c}{ Compound } & $\mathbf{L}_{\mathbf{1}}$ & $\mathbf{1}$ & $\mathbf{3}$ & 4: with L2 ligand & $\mathbf{2}$ \\
\hline $\begin{array}{l}\text { Formula } \\
\text { Hydrogen } \\
\text { Contacts }{ }^{*} \text { and Angles }\end{array}$ & $\mathrm{C}_{7} \mathrm{H}_{7} \mathrm{NO}_{2} \mathrm{~S}$ & $\mathrm{C}_{14} \mathrm{H}_{18} \mathrm{Cl} 2 \mathrm{~N}_{2} \mathrm{NiO}_{14} \mathrm{~S}_{2}$ & $\mathrm{C}_{14} \mathrm{H}_{20.2} \mathrm{~N}_{2} \mathrm{O}_{15.1} \mathrm{~S}_{2} \mathrm{Cl}{ }_{2} \mathrm{Co}$ & $\mathrm{C}_{22} \mathrm{H}_{34} \mathrm{~N}_{2} \mathrm{O}_{18} \mathrm{~S}_{2} \mathrm{Cl}_{2} \mathrm{Co}_{2}$ & $\mathrm{C}_{21} \mathrm{H}_{23} \mathrm{~N}_{3} \mathrm{O}_{15} \mathrm{~S}_{3} \mathrm{Cl}_{2} \mathrm{Mn}$ \\
$\mathrm{N} 1-\mathrm{H} \ldots \mathrm{O}(\mathrm{X})$ & & & & \\
& & & & \\
$\mathrm{N} 2-\mathrm{H} \ldots \mathrm{O}(\mathrm{Y})$ & $2.24(2) ; 168(2)^{\circ}$ & $2.17(2) ; 173(3)^{\circ}$ & $2.12(2) ; 168(3)^{\circ}$ & $2.30(3) ; 166(3)^{\circ}$ & $2.23(2) ; 166(2)^{\circ}$ \\
$\mathrm{N} 3-\mathrm{H} \ldots \mathrm{O}(\mathrm{Z})$ & & $2.17(2) ; 166(3)^{\circ}$ & $2.63(2) ; 162(3)^{\circ}$ & & $2.58(3) ; 125(2)^{\circ}$ \\
\hline
\end{tabular}

* The hydrogen-bonded contacts involve oxygens on the perchlorate anions for compounds $\mathbf{1}-\mathbf{4}$. O(X) represents O2 for $\mathbf{L}_{\mathbf{1}}, \mathrm{O} 7$ for $\mathbf{1}$ and $\mathbf{4}, \mathrm{O} 8$ for $\mathbf{3}$, and $\mathrm{O} 13$ for $\mathbf{2}$. $\mathrm{O}(\mathrm{Y})$ is $\mathrm{O} 14$ for $\mathbf{1}, \mathrm{O} 11$ and $\mathrm{O} 11$ ' for $\mathbf{3}, \mathrm{O} 8$ and $\mathrm{O} 11$ for $\mathbf{2}$. $\mathrm{O}(\mathrm{Z})$ is $\mathrm{O} 14$ for $\mathbf{2}$. 


\section{(table 4)}

Table 4. Infrared frequencies of Complexes 1-4 (MTI = methylthienylimide)

\begin{tabular}{|c|c|c|c|c|c|c|}
\hline Infrared & Spectra & $\mathrm{cm}^{-1}$ & & & & Assignments \\
\hline 2-MTI & Co 2-MTI & Mn 2-MTI & Ni 2-MTI & 3-MTI & Co 3-MTI & \\
\hline $3360, \mathrm{vw}$ & $3321, \mathrm{vw}$ & $3334, \mathrm{w}$ & $3327, \mathrm{vw}$ & & & \\
\hline $3275, \mathrm{~m}$ & & & 3263 , vw & $3286, \mathrm{~m}$ & & $\mathrm{~N}-\mathrm{H}$ \\
\hline $3163, \mathrm{vw}$ & & & & $3120, \mathrm{w}$ & & \\
\hline $3110, w$ & $3106, \mathrm{vw}$ & $3108, \mathrm{w}$ & $3107, \mathrm{vw}$ & & & C-H-ring \\
\hline \multirow[t]{3}{*}{ 3095, w } & & & & $3098, \mathrm{~m}$ & & $\mathrm{C}-\mathrm{H}$ ring \\
\hline & & & & 2972, vvw & & \\
\hline & & & & 2932, vvw & & \\
\hline $1703, \mathrm{~m}$ & $1688, \mathrm{~s}$ & 1709, vs & $1691, \mathrm{~s}$ & $1690, \mathrm{~s}$ & & $\mathrm{C}=\mathrm{O}$ \\
\hline 1674, vs & $1647, \mathrm{~s}$ & $1643, \mathrm{vs}$ & $1647, \mathrm{~s}$ & $1672, \mathrm{~s}$ & & $\mathrm{C}=\mathrm{O}$ \\
\hline $1522, \mathrm{~m}$ & $1518, \mathrm{w}, \mathrm{sh}$ & $1519, \mathrm{w}, \mathrm{sh}$ & 1517, w, sh & $1514, \mathrm{~m}$ & & \\
\hline $1471, \mathrm{~m}$ & $1478, \mathrm{~s}$ & $1475, \mathrm{~s}$ & $1481, \mathrm{~s}$ & $1463, \mathrm{~m}$ & & \\
\hline $1408, \mathrm{~m}$ & $1412, \mathrm{~m}$ & $1411, \mathrm{~m}$ & $1412, \mathrm{~m}$ & $1402, \mathrm{w}$ & & \\
\hline $1377, \mathrm{~m}$ & $1376, \mathrm{w}$ & 1381, vw & $1377, \mathrm{vvw}$ & $1374, \mathrm{~s}$ & & \\
\hline \multirow[t]{2}{*}{$1353, \mathrm{~m}$} & $1358, \mathrm{~m}$ & $1358, \mathrm{~ms}$ & $1358, \mathrm{~ms}$ & & & \\
\hline & $1317, \mathrm{w}$ & $1306, \mathrm{w}$ & $1318, \mathrm{vw}$ & & & \\
\hline $1288, \mathrm{~s}$ & & & & $1291, \mathrm{~s}$ & & \\
\hline $1259, \mathrm{~s}$ & $1255, \mathrm{~s}$ & $1250, \mathrm{~s}$ & $1255, \mathrm{~s}$ & $1255, \mathrm{~s}$ & & \\
\hline \multirow[t]{4}{*}{1238, vs } & $1236, \mathrm{vs}$ & $1221, \mathrm{vs}$ & $1238, \mathrm{vs}$ & $1231, \mathrm{~s}$ & & \\
\hline & & & & $1218, \mathrm{~m}$ & & \\
\hline & & & & $1186, \mathrm{~m}$ & & \\
\hline & & & & 1112, w & & \\
\hline $1092, \mathrm{~m}$ & & & & $1088, \mathrm{~m}$ & & \\
\hline $1073, \mathrm{~m}$ & 1072, vs & $1070, \mathrm{vs}$ & 1069 , vs & $1074, \mathrm{w}$ & & $\mathrm{ClO}$ \\
\hline $1043, \mathrm{w}$ & & & & $1043, \mathrm{w}$ & & \\
\hline \multirow[t]{2}{*}{$1015, \mathrm{~m}$} & & & & $1020, \mathrm{~ms}$ & & \\
\hline & $951, w$ & $945, w$ & $948, \mathrm{vw}$ & 946, vw & & \\
\hline \multirow[t]{2}{*}{$920, \mathrm{w}$} & $932, \mathrm{w}$ & 932, vvw & 932, vw & & & \\
\hline & & & & 893,884 , wd & & \\
\hline $870, w$ & $869, \mathrm{w}$ & $868, w$ & $868, \mathrm{w}$ & & & \\
\hline $860, \mathrm{~m}$ & & & & $856, \mathrm{~m}$ & & \\
\hline $842, w$ & & & & $845, \mathrm{~m}$ & & \\
\hline \multirow[t]{2}{*}{$820, \mathrm{~m}$} & $814, w$ & $807, \mathrm{w}$ & $816, \mathrm{w}$ & $828, \mathrm{~s}$ & & $\mathrm{C}-\mathrm{S}$ \\
\hline & & & & $791, w$ & & \\
\hline $777, \mathrm{~m}$ & & & & $771, \mathrm{~m}$ & & $\mathrm{C}-\mathrm{S}$ \\
\hline \multicolumn{7}{|l|}{$756, \mathrm{w}$} \\
\hline \multirow[t]{2}{*}{$730, \mathrm{~s}$} & $732, \mathrm{~s}$ & $738, \mathrm{~s}$ & $733, \mathrm{~s}$ & 739 , vs & & \\
\hline & & & & $718,711, \mathrm{md}$ & & \\
\hline $666, \mathrm{w}$ & 679, vvw & $674, \mathrm{vw}$ & 679, vw & $657, \mathrm{vvw}$ & & \\
\hline
\end{tabular}




\section{Figures}

(Figure 1)
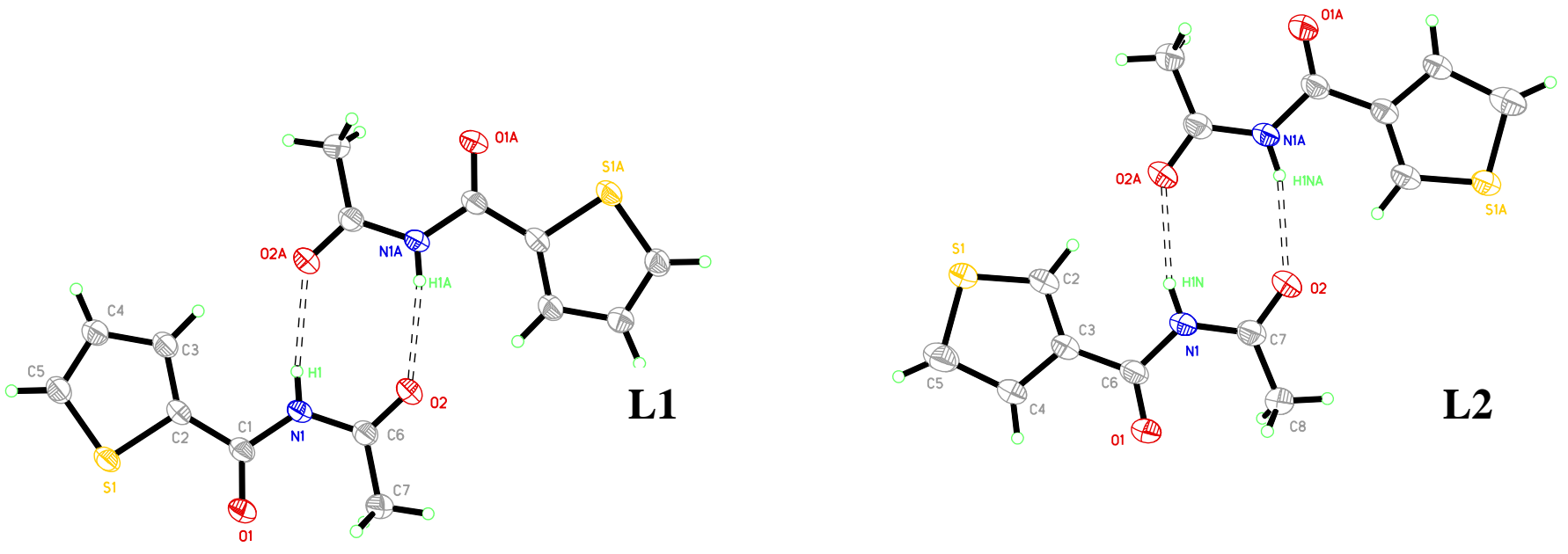
(Figure 2)

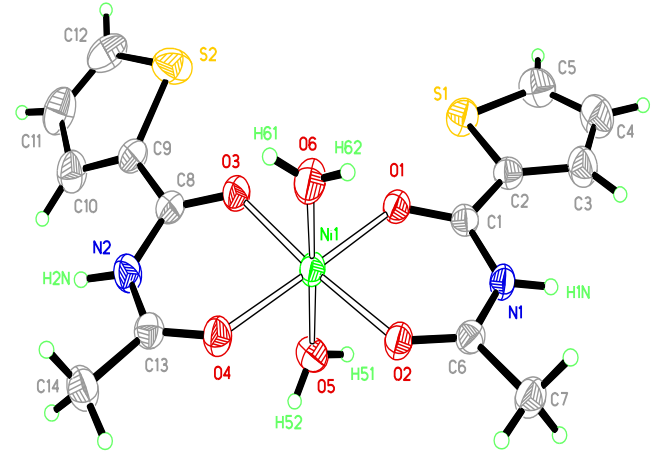

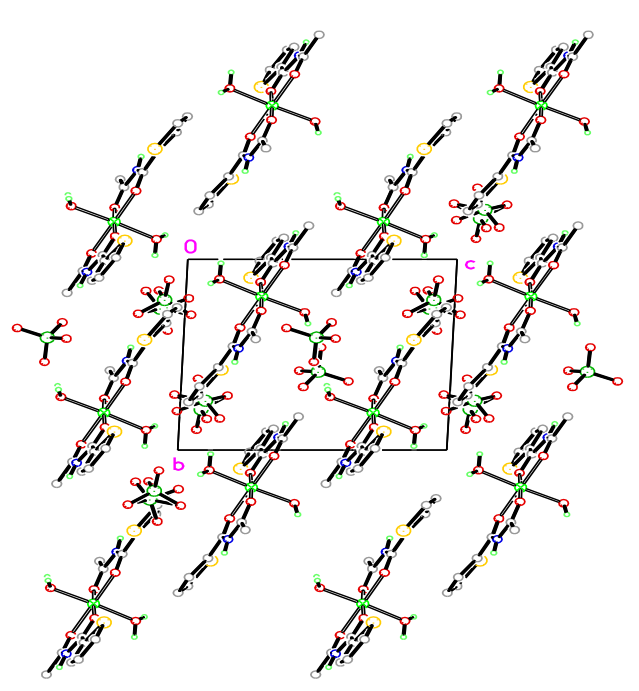


Fig. 3
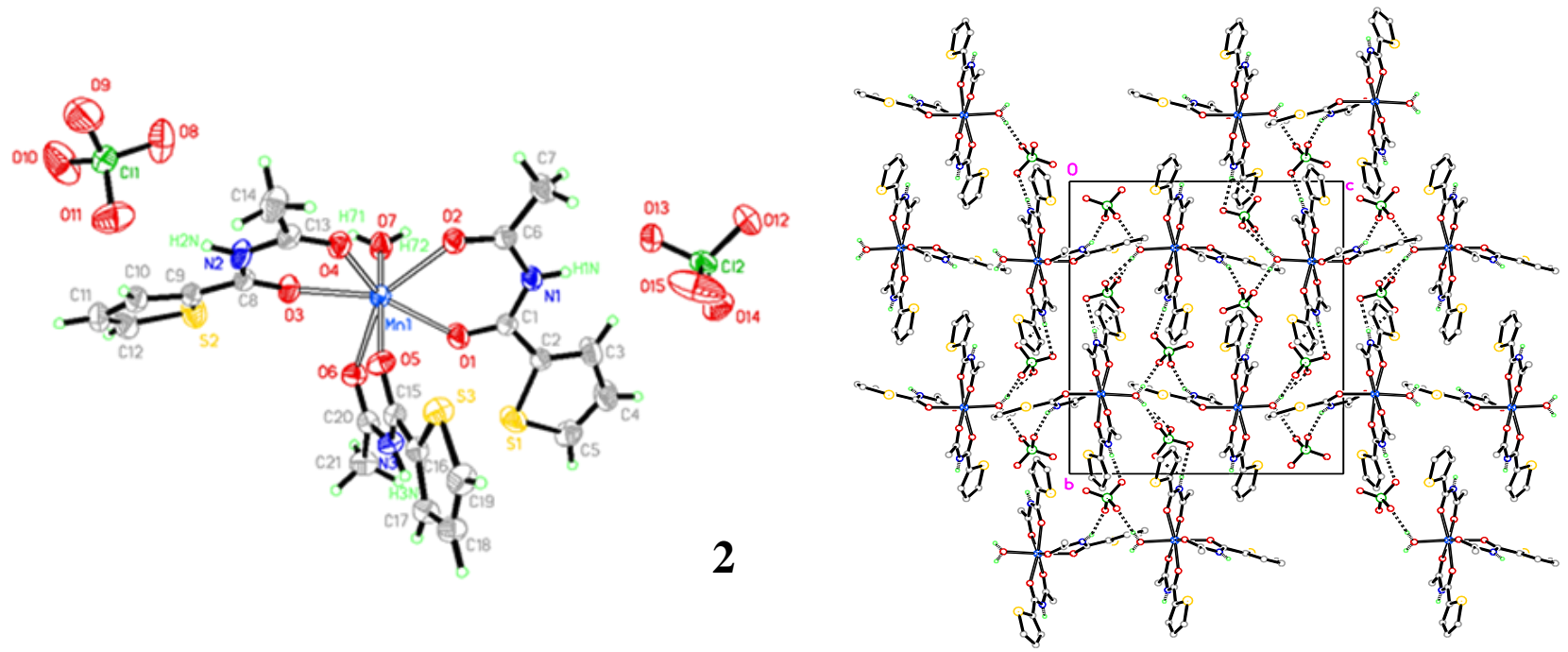
Fig. 4

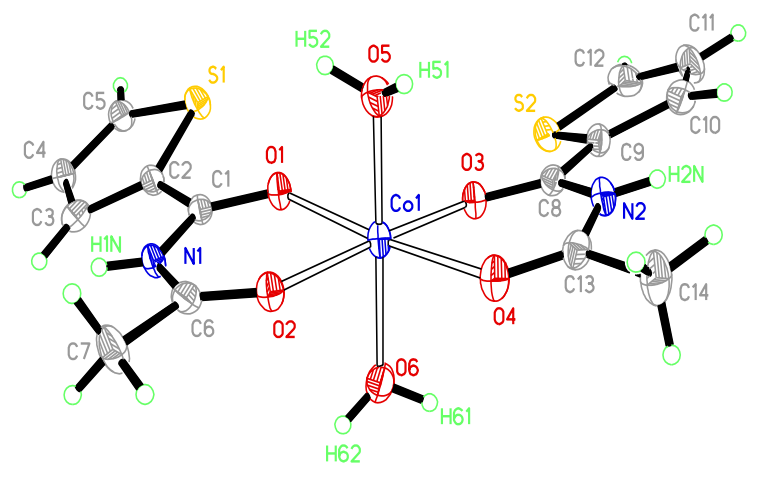

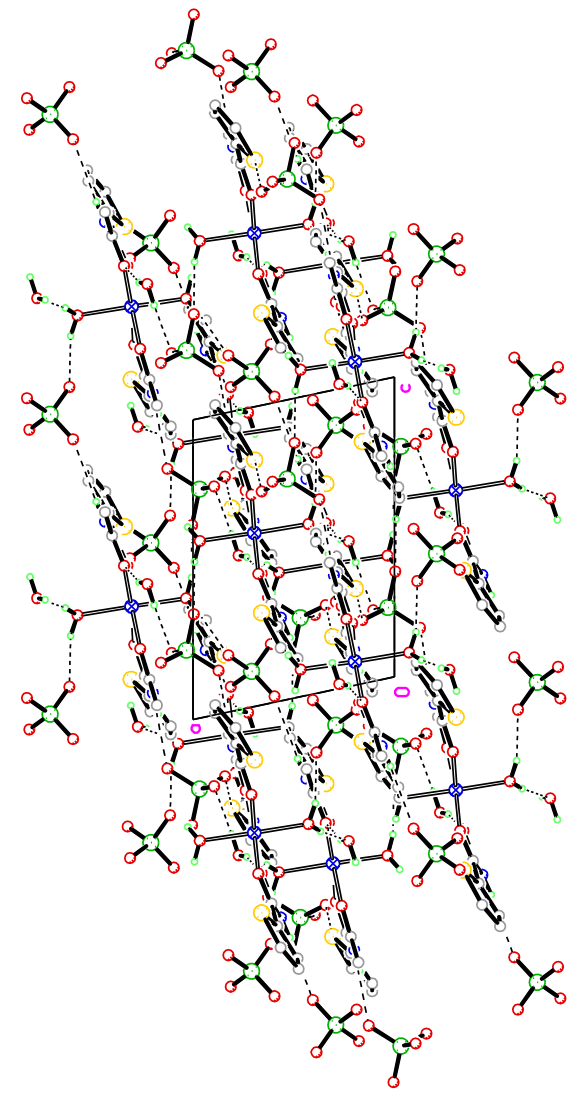


Fig. 5
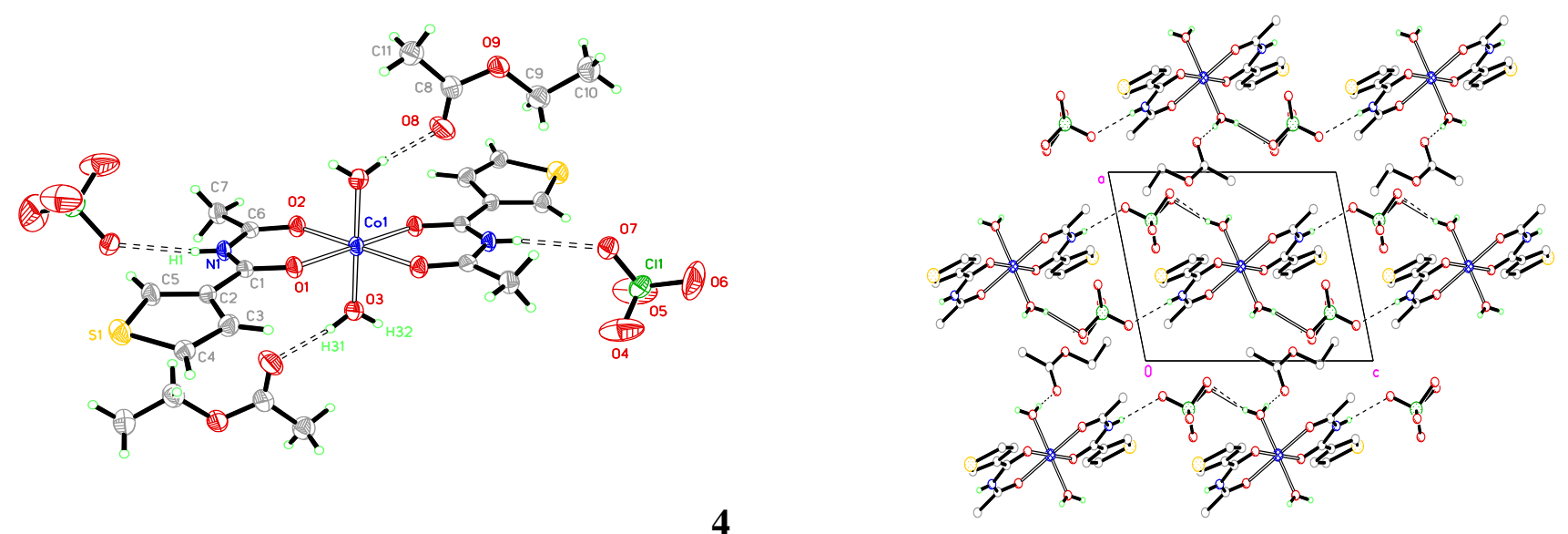
Graphical Abstract

Synthesis and Characterization of Complexes Formed by Transition Metal Ions With Thiophene Imides As Potential Precursors To Metal Ion Uptake and Release Agents

Rosalva C. Garcia, Kasha Patel, Cynthia S. Day, and Ronald E. Noftle

Department of Chemistry, Wake Forest University, Winston-Salem, NC 27109, USA
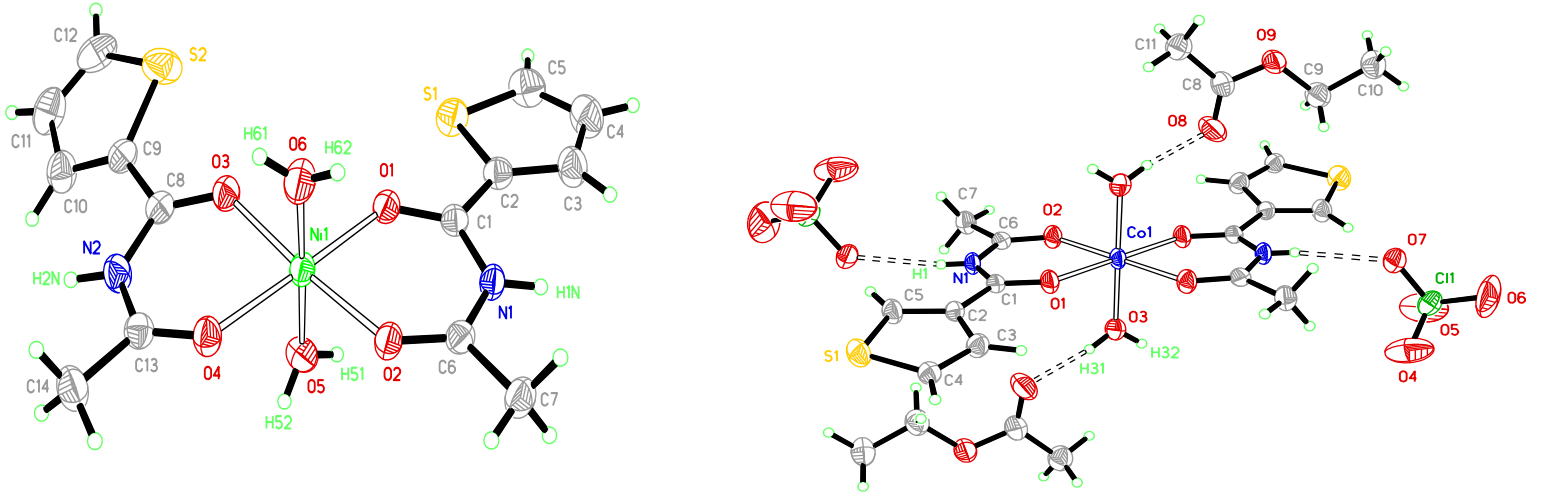


\begin{abstract}
It was found that methyl-2-thienylimide $\left(\mathbf{L}_{1}\right), \mathrm{C}_{4} \mathrm{H}_{3} \mathrm{SC}(\mathrm{O}) \mathrm{NHC}(\mathrm{O}) \mathrm{CH}_{3}$, could act as a ligand and combine with metal(II) perchlorates $\left(\mathrm{Ni}^{2+}, \mathrm{Mn}^{2+}\right.$, and $\left.\mathrm{Co}^{2+}\right)$ to produce complexes for potential use as metal ion uptake and release agents in polymer form. Methyl-3-thienylimide $\left(\mathbf{L}_{2}\right)$ formed a similar complex with $\mathrm{Co}^{2+}$. The synthesis and structures obtained from single crystal x-ray diffraction data are reported. The carbonyl groups in the ligands are cis/trans with respect to the $\mathrm{N}-\mathrm{H}$ group in the solid state but are necessarily trans-trans in the complex. The ligands are bidentate, forming bonds to the metal ions through the imide oxygen atoms; the imide ligands are protonated. The cobalt and nickel complexes have two bidentate ligands in the equatorial positions and two water molecules in the apical positions with the ligands $\mathrm{cis}$ to each other in the case of methyl-2-thienylimide while they are trans in the cobalt complex formed by methyl-3thienylimide. The manganese complex is seven coordinate with three bidentate ligands and one water molecule. Significant hydrogen bonding is present in all of the complexes leading to the formation of 2D networks in two cases and an infinite chain in one. IR, and UV-Visible spectroscopy along with elemental analyses are also presented.
\end{abstract}

